\title{
POSSIBILITY OF RADIOLOGICAL DIAGNOSTICS OF SPLENIC ARTERY PSEUDOANEURYSM - A CASE REPORT AND REVIEW OF LITERATURE
}

\author{
Miroslav Mišović1,2, Jelena Golubović ${ }^{1}$, Igor Sekulić ${ }^{1}$, Saša Dragović ${ }^{3}$, Nemanja Rančić1,2
}

\begin{abstract}
Splenic artery pseudoaneurysm (SAP) is extremely rare, but potentially fatal medical condition. In the literature to date, pseudoaneurysms of the splenic artery were described in less than 250 cases. The most frequent cause of this rare condition is pancreatitis. Patients with splenic artery pseudoaneurysms are almost always presented by severe clinical symptoms. Ruptured pseudoaneurysms can cause fatal complications. The aim of this study was to present radiological possibilities in diagnostics of SAP in a patient suffering from chronic pancreatitis. Patient was initially advised for Ultrasound and Color Dopller sonography where lesion suspicion for SAP was made. Further, CT angiography and DSA were performed to provide certain diagnosis. The patient was surgically treated and histopathological examination definitely confirmed diagnose of SAP.
\end{abstract}

Acta Medica Medianae 2019;58(3):177-183. \section{$C T, D S A$}

Key words: splenic artery pseudoaneurysm, radiological diagnostics, ultrasound,

\author{
${ }^{1}$ Institut \\ Defense, Belgrade, Serbia \\ Belgrade, Serbia \\ Contact: Miroslav Mišović \\ Crnotravska 17, 11000 Belgrade, Serbia \\ E-mail: miki_misic@yahoo.com
}

${ }^{2}$ Medical Faculty of the Military Medical Academy, University of

${ }^{3}$ Clinic for General Surgery, Military Medical Academy, ent with symptoms (3). The aim of this article is a case report with literature review of the clinical features, radiological appearance and management of SAP.

\section{Case presentation}

We present a 49-year-old patient with history of chronic pancreatitis and alcohol abuse. In the period of last two months, he complained about the occasional pulsating pain in the upper abdomen so he was hospitalized with suspicion of SAP.

After a clinical examination, the patient was advised for abdominal ultrasound (US) and color Doppler sonography (CDS) examination which was performed with $\mathrm{CH}$ 6- 2 abdominal probe on Siemens Acuson Antares ultrasound machine.

In the region of the pancreas body, US revealed an oval, well defined, multilayered, thick walled, cystic lesion, dimension $6 \times 5.5 \mathrm{~cm}$ (Figure 1) with CDS registered turbulent blood flow (Figure 2). The lesion is with short and narrow neck associated with splenic artery. In the neck of the lesion it was registered characteristic bidirectional high-speed flows by the type so called "to and fro" with peak systolic velocity (PSV) up to $250 \mathrm{~cm} / \mathrm{s}$ (Figure 3).

In a continuation of diagnostics, Computed Tomography (CT) angiography of the abdomen was performed on Toshiba Aquilion 64 CT scanner. The examination was done with intravenously administered contrast medium in the arterial, early and late venous phase. literature to date, SAPs were described in less than 250 cases (6). Unlike SAA, SAPs nearly always pres- 


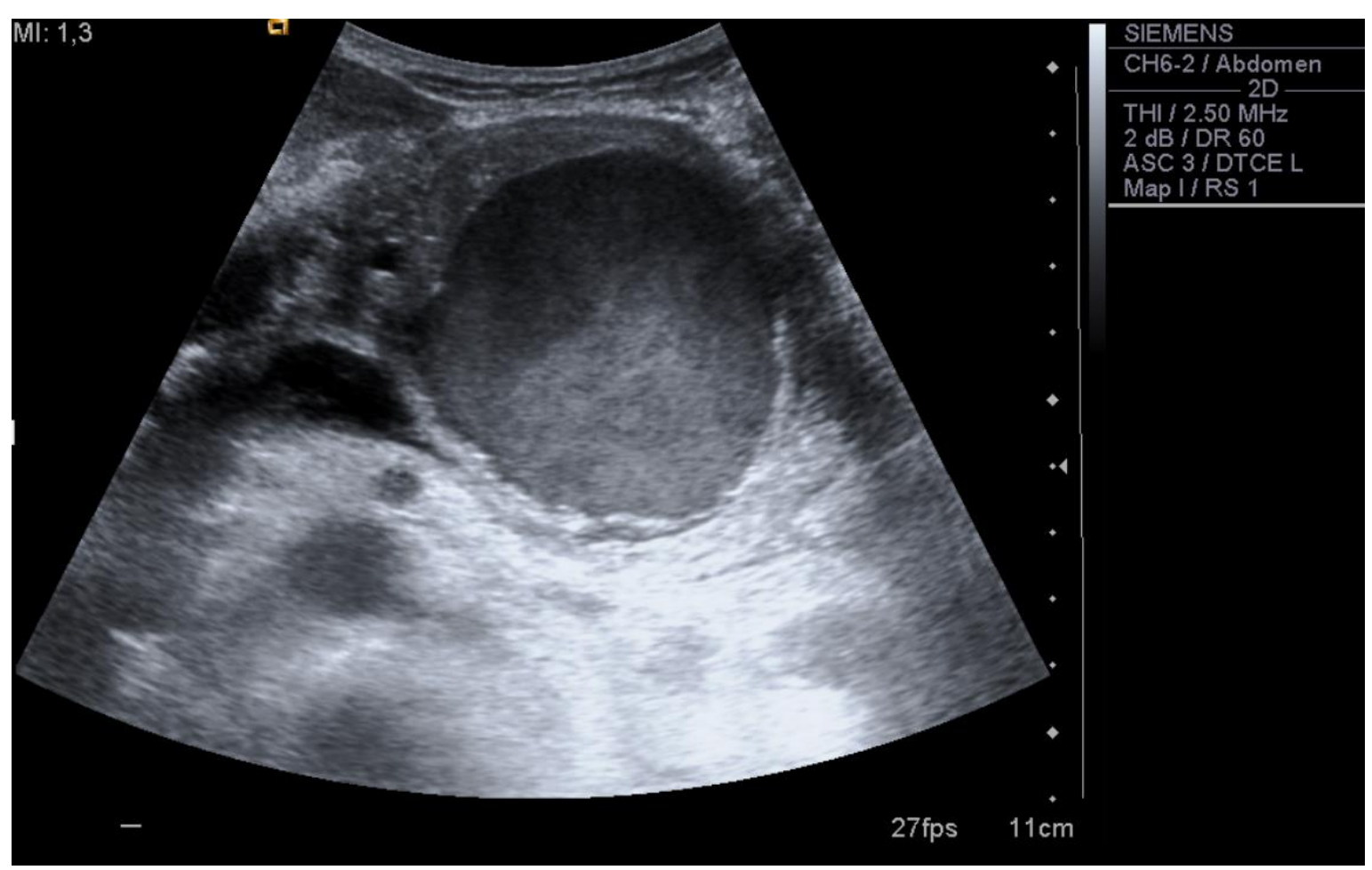

Figure 1. Ultrasound image of SAP

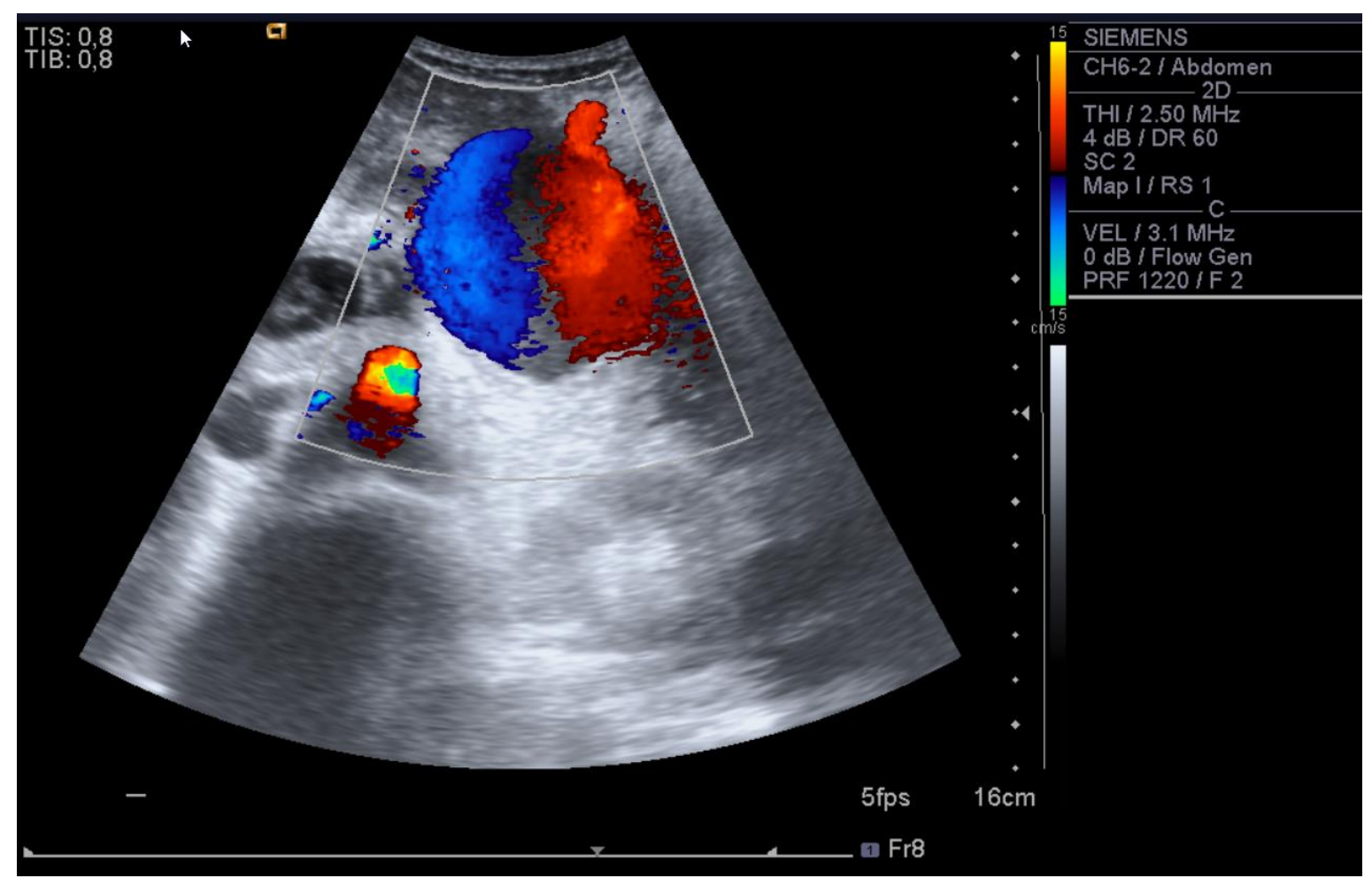

Figure 2. CDS registered turbulent blood flow 


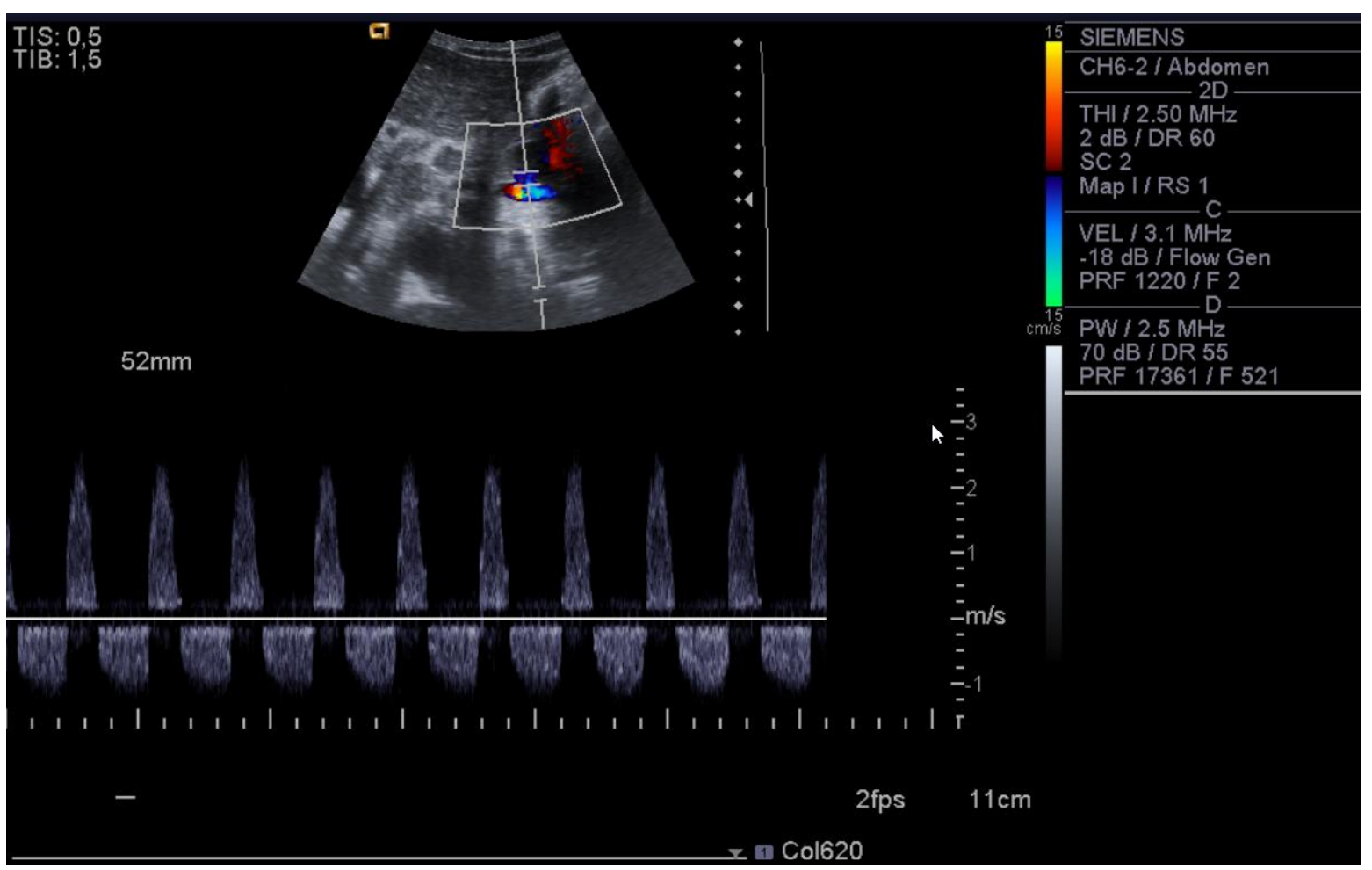

Figure 3. Characteristic bidirectional high- speed flows in the neck of SAP

An examination of the arterial phase presents the common hepatic artery, a splenic artery, and an upper mesenteric artery with its branches. In the proximal third of the splenic artery, retropancreatically, it is presented as an oval, smoothly marginated formation with thicker walls, measuring about
$5 \times 5 \mathrm{~cm}$ and showing gradual enhancement, with maximum densities reaching in the late venous phase probably because of the extremely thin SAP neck (Figure 4). The aforementioned formation could be differentiated as pseudoaneurysm of the splenic artery with thin neck.

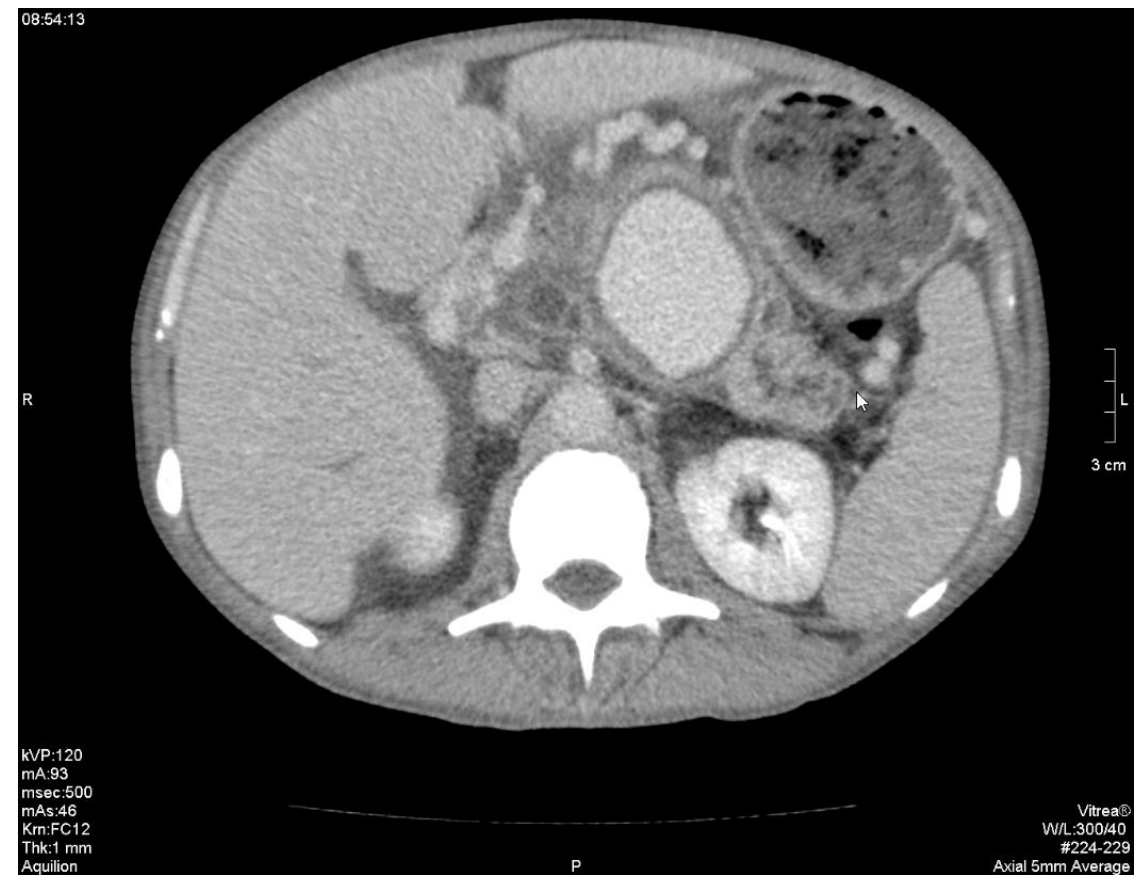

Figure 4. CT axial image of SAP, late venous phase 


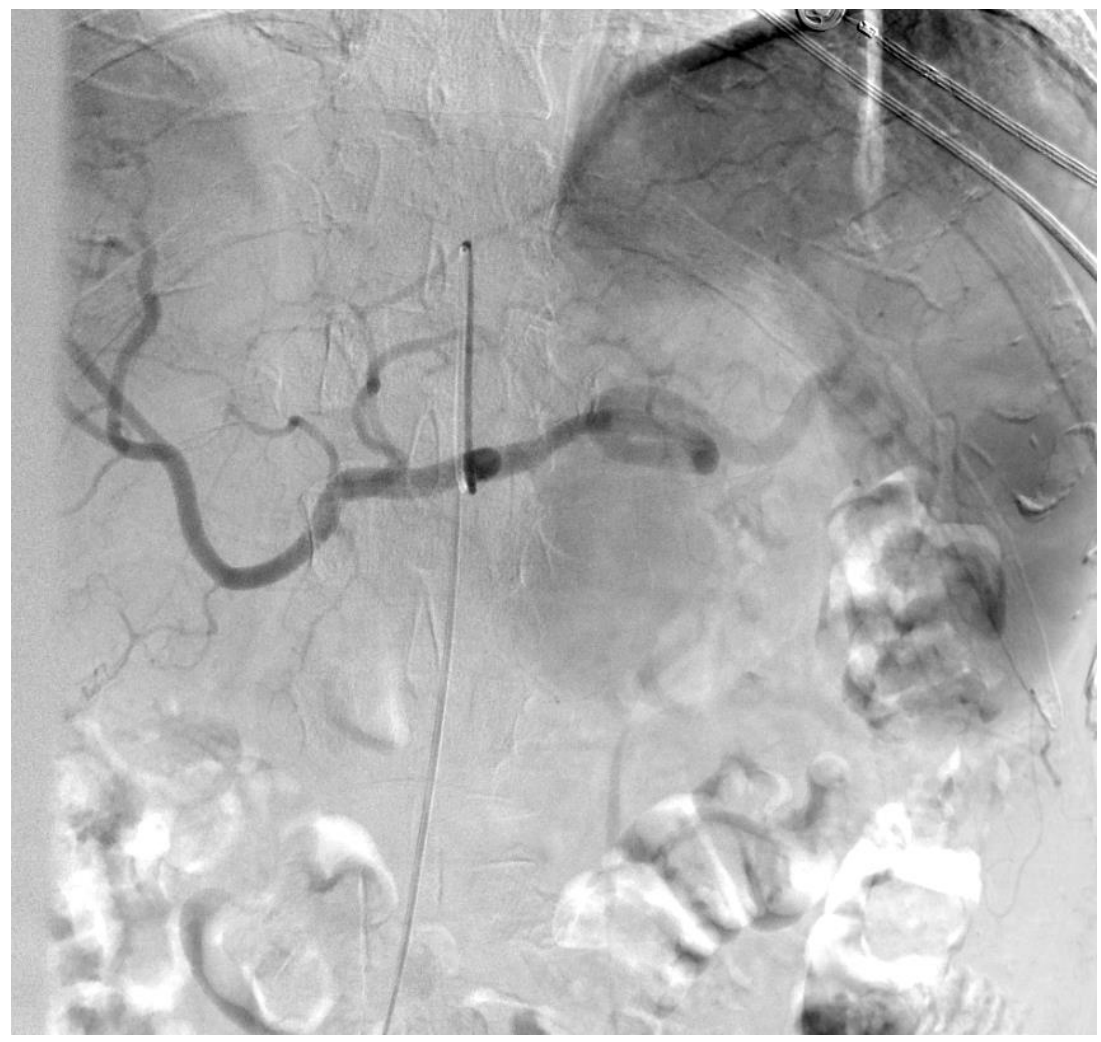

Figure 5. DSA shows extravasation of the contrast medium in SAP

For the purpose of additional diagnostics, digital subtractional angiography (DSA) of the celiac trunk was indicated and implemented.

At the level of the proximal third of the splenic artery, it is observed extravasation of the contrast medium in the previously described lesion, which corresponds to the pseudoaneurysm of the splenic artery (Figure 5).

After appropriate radiological diagnostics, patient was treated surgically by radical splenic artery ligation and splenectomy with distal pancreatectomy. Histopathological verification of previously observed and resected lesion confirmed that it was a pseudoaneurysm of splenic artery.

\section{Discussion}

An insight into available literature shows that a typical patient with SAP is about 52 years old (range, 35-78 years), suffers from chronic pancreatitis and has a history of alcohol abuse as the case of our patient was (7).

The most common etiology of SAP is panreatitis, precisely recurrent acute or chronic form, even though, less common cause is the first episode of acute pancreatitis (5). A large proportion of patients have a significant history of alcohol intake (7). It is estimated that up to $21 \%$ of patients with chronic pancreatitis and $10 \%$ patients with chronic pancreatitis and pseudocyst develop SAP as additional complication $(8,9)$. Blunt and penetrating trau- ma as well as iatrogenic trauma or peptic ulcer disease are less common causes (10). In a small number of SAP, there is no identifiable cause (7).

Pseudoaneurysm based on pancreatitis is caused by at least three different mechanisms:

1. enzymatic digestion of the adjacent artery wall by peripancreatic fluid within a pseudocyst, forming necrotising arteritis with fragmentation of elastic tissues

2. local compression of the blood vessel wall by longstanding pseudocyst, which can cause vascular erosion and weakness of the vessel wall architecture or

3. aneurysmal rupture into pseudocyst leading to pseudoaneurysm $(5,8)$. Splenic artery is the most frequently affected blood vessel (30-50\%) (5).

Normal diameter of the splenic artery is in range from $0.43 \mathrm{~cm}$ to $0.49 \mathrm{~cm}$. The splenic artery is aneurysmal dilatated when a focal diameter is greater than $50 \%$ compared to the normal vessel lumen. True aneurysms involve all 3 layers (intima, media and adventitia), while pseudoaneurysms forming a false lumen, so that consist of only one or two layers (9).

Retrospective case series reported different size of splenic artery pseudoaneurysms, from $2 \mathrm{~cm}$ to $17 \mathrm{~cm}$ (mean diameter $4.8 \mathrm{~cm}$ ), similar to our measurements $5.5 \times 6 \mathrm{~cm}$ on US examination and $5 \times 5 \mathrm{~cm}$ on CT angiography respectively (7). Thus, we could suspect SAP based only on the history of the disease and US and CDS examination results. Further, we were able to conclude that there was no 
significant difference in the dimensions of the lesion, either measured by the ultrasound or CT examination.

The literature data leads to the conclusion that the size of SAP is not a predictor of rupture (9). Pseudoaneurysms, independent of their size, are more prone to rupture because of lack a true wall unlike true splenic aneurysms with all three intact layers wall. Larger pseudoaneurysms probably originate from rupture into a pseudocyst (8).

The most accurate term for pseudoaneurysm is pulsatile hematoma, which describes both disease and the high risk of rupture without treatment (11). Clinical diagnosis of SAP is challenge because its presentation often varies from an incidental finding to hemodynamic collapse from sudden rupture and bleeding (6). Patients with SAP are almost always presented by severe clinical symptoms such as an episode of abdominal pain - $29.5 \%$, melena and tarry stool - $26.2 \%$, hematochezia (vomiting blood) - $14.8 \%$ or ischemic symptoms of affected organ which is consequence of intermittent embolism. Acute and massive hemorrhage with the loss of large amounts of blood can cause hemorrhagic shock (5, 12). Ruptured pseudoaneurysms can cause fatal complications due to massive gastrointestinal bleeding in the pancreatic duct, termed "hemosuccus pancreaticus", which is the main cause of hemobilia, hematemesis, hematochezia or melena. Rupture can also occur into the nearby organs, peritoneum, retroperitoneum or form a pseudocyst (9). It is estimated that the risk of rupture of a SAP is about $37 \%$, with the mortality rate of $90 \%$ for the untreated ones (3). Except early rupture complications of pseudoaneurysms also include, compression of nearby structures and a high frequency of aneurysm infection (11).

The US with CDS, is low cost, wide available, real time and very informative hence is usually the first diagnostic modality for abdomen and pelvic pathologies. It can be useful for detecting SAP, as well as belonging neck. Accurate and reliable diagnosis, in fact, requires additional diagnostics methods such as CT angiography and DSA. A CT is the most commonly used diagnostic tool for evaluation of all visceral pseudoaneurysms.

On US imaging, pseudoaneurysm commonly appears as multilayered lesion with central or peripheral anechoic area continuous with arterial lumen, showing continuous arterial pulsation on real time ultrasonography if SAP is from the splenic artery. Continuous arterial pulsation is not visualized if pseudoaneurysm arising from the small artery or when only small part of lesion is continuous with arterial lumen. Sonographic appearance of pseudoaneurysm depends on the size of the lesion, patency of vessel and aneurysmal lumen, presence of hemorrhage and thrombus, and level of calcification (6). This technique is depending on the surgeon and also may be limited by obesity, shadowing from bowel gas or massive arteriosclerosis which can interfere with retroperitoneal and mesenteric vessels obscuring visualisation. Limited spatial resolution may cause missing small lesions on sonography (3). On CDS examination, because of the turbulent forward and backward flow, there may be seen characteristic "yin- yang" sign, while a "to and fro" sign may be seen with pulsed wave Color Doppler.

A CT angiography is very useful method for confirming the diagnosis as well as presenting the anatomy, size and extent of the lesion, character and continuation of pseudoaneurysm with parent vessel, detecting extent of thrombus, hemorrhage and status of adjacent organs. On CT, pseudoaneurysm appears during the arterial phase, which is most important for identifying these lesions. A SAP is at imaging similar as aneurysms with the more irregular margin, presented as hypodense or multilayered lesion which is continuous with the parent artery and typically surrounded by a hematoma (3, $5,11)$. If acute hemorrhage is present, it will be demonstrated as hyperdense area. The presence of gas suggests a gastrointestinal fistula, and the lack of very high-density oral contrast suggests that the lesion does not communicate with the gastrointestinal tract (6). New generation scanners with a large number of detector rows with multiplanar reconstruction (MPR) capabilities as well as three-dimensional renderings ( $3 D$ rendering) allow identification of aneurysms and pseudoaneurysms, better separation of smaller aneurysms from tortuous blood vessel or hyperattenuating islet cell tumor of the pancreas. Multiplanar reconstruction (MPR) and 3D rendering of the lesion is useful for a better evaluation of the whole condition (3). Relative contraindications to CT angiography are renal insufficiency, poor intravenous access, and allergy to contrast agents.

Magnetic resonance imaging (MRI) and MRI angiography are useful diagnostic modalities in patients with chronic renal failure, because of the use of potentially less nephrotoxic contrast agents, although MRI can detect vascular flow without applying contrast material (11). Contraindication for MRI includes patients with pacemakers or aneurysm clips, while relative contraindications include patients suffering from claustrophobia, or unable to hold their breath (3).

In hemodynamically stable patients, preoperative DSA helps confirming the diagnosis, define the character of the lesion and allows therapeutic planning. In a high-risk patient, with bleeding vessel, preoperative DSA might gain temporary control of hemorrhage by performing transcatheter embolization, thus providing a time window for operation under optimum clinical conditions (5). DSA is the most specific diagnostics, but also may be a therapeutic method, so it is the gold standard for identification of artery aneurysms and pseudoaneurysms (8). In carefully selected patients, endovascular visceral aneurysm artery reconstruction with stent graft can be a reasonable method of treatment, as a safer option and an alternative to open surgical repair (13).

Almost all visceral pseudoaneurysms require treatment because of the tendency of continuous enlargement, great risk of rupture, and consequently significant mortality (11). In the past, the most commonly used treatment of SAP was radical splenic artery ligation, splenectomy with or without pancreatectomy (distal, partial or total) (14). Nowadays, endovascular, less invasive approach, for uncomplicated pseudoaneurysms in hemodynamically stable 
patients, is increasingly in use with better outcomes and less morbidity (9). The treatment of choice is coil embolization or stent-graft placement across the lesion when the anatomy allows (11). Endovascular procedures have less severe complications such as splenic infarction or postembolization syndrome (12). If surgical intervention and arterial embolization are not possible or not feasible, percutaneous US or CTguided application of thrombin can be performed for the first-line treatment (8).

\section{Conclusion}

SAP is a potentially life-threatening condition that can be difficult to diagnose. It is important to make the distinction between visceral aneurysm and pseudoaneurysm for further treatment and prognostic opportunities. SAP can be diagnosed by clinical approach, US with CDS examination, CT angiography, MRI angiography and DSA. The CT is proven to be quite valuable method, but DSA is considered to be the gold standard due to better spatial resolution and potentially successful treatment method.

Death rate in untreated pseudoaneurysms is not neglectable, so that, radiologists, who identify these vascular pathologies, have to recognize the clinical significance and understand the management because prompt and well-timed treatment depends directly on fast and accurate radiological diagnosis.

\section{References}

1. Sułkowski L, Szura M, Pasternak A, Matyja M, Matyja A. Pathogenesis, diagnosis and treatment of splenic artery aneurysms. Austin J Vasc Med 2016; 3(1): 1017. [CrossRef]

2. Dong SL, Chen X, Tu ZX, Ai X, Zhang ZW, Guan Y, et al. Aneurysm of the anomalous splenic artery arising from superior mesenteric artery treated by coil embolization: a report of two cases and literature review. Ann Vasc Surg 2018; 48: 251.e5-251.e10. [CrossRef][PubMed]

3. Agrawal GA, Johnson PT, Fishman EK. Splenic artery aneurysms and pseudoaneurysms: clinical distinctions and CT appearances. Am J Roentgenol 2007; 188(4): 992-9. [CrossRef][PubMed]

4. Gandhi VS, Thakkar GN, Rajput DK, Rajvaidya NP. Splenic artery aneurysm. Ind J Radiol Imag 2006; 16(4): 487-9. [CrossRef]

5. Soni HC, Patel SB, Goswami KG. Case Report: pseudoaneurysm of splenic artery. Ind J Radiol Imag 2006; 16(4): 509-11. [CrossRef]

6. Schatz RA, Schabel S, Rockey DC. Idiopathic splenic artery pseudoaneurysm rupture as an uncommon cause of hemorrhagic shock. J Investig Med High Impact Case Rep 2015; 3(2): 2324709615577816. [CrossRef][PubMed]

7. Tessier DJ, Stone WM, Fowl RJ, Abbas MA, Andrews JC, Bower TC, et al. Clinical features and management of splenic artery pseudoaneurysm: case series and cumulative review of literature. J Vasc Surg 2003; 38 (5): 969-74. [CrossRef][PubMed]
8. Micković $S$, Mitrović $M$, Stanković N, Bezmarević M, Jovanović M, Mirković D, et al. Splenic artery pseudoaneurysm as a complication of pancreatic pseudocyst. Vojnosanit Pregl 2011; 68(7): 602-6.

[CrossRef][PubMed]

9. Kassem MM, Gonzalez L. Splenic artery aneurysm. NCBI Bookshelf. 2017. [PubMed]

10. Abbey-Mensah G, Herskowitz MM, Walsh J, Leonardo RF. Massive hematemesis from a splenic artery pseudoaneurysm presenting two years after penetrating trauma. Case Reports in Radiology 2018; 2018: 7473168. [CrossRef][PubMed]

11. Jesinger RA, Thoreson AA, Lamba R. Abdominal and pelvic aneurysms and pseudoaneurysms: imaging review with clinical, radiologic, and treatment correlation. Radiographics 2013; 33(3): E71-96. [CrossRef][PubMed]

12. Kukliński A, Batycki K, Matuszewski W, Ostrach A, Kupis Z, Łęgowik T. Embolization of a large, symptommatic splenic artery pseudoaneurysm. Pol J Radiol 2014; 79: 194-8. [CrossRef][PubMed]

13. Marjanović I, Jevtić M, Mišović S, Rusović S, Zoranović $U$, Šarac M. Endovascular reconstruction of giant gastroduodenal artery aneurysm with stent graft: case report. Vasc Endovascular Surg 2010; 44(5): 392-4. [CrossRef][PubMed]

14. Chia C, Pandya GJ, Kamalesh A, Shelat VG. Splenic artery pseudoaneurysm masquerading as a pancreatic cyst- a diagnostic challenge. Int Surg 2015; 100(6): 1069-71. [CrossRef][PubMed] 


\title{
MOGUĆNOSTI RADIOLOŠKE DIJAGNOSTIKE PSEUDOANEURIZMI LIJENALNE ARTERIJE - PRIKAZ SLUČAJA I PREGLED LITERATURE
}

\author{
${ }^{1}$ Institut za radiologiju, Vojnomedicinska akademija, Beograd, Srbija \\ ${ }^{2}$ Medicinski fakultet Vojnomedicinske akademije, Univerzitet odbrane, Beograd, Srbija \\ ${ }^{3}$ Klinika za opštu hirurgiju, Vojnomedicinska akademija, Beograd, Srbija \\ Kontakt: Miroslav Mišović \\ Crnotravska 17, 11000 Beograd, Srbija \\ E-mail:miki_misic@yahoo.com
}

Miroslav Mišović1, ${ }^{2}$, Jelena Golubović ${ }^{1}$, Igor Sekulić ${ }^{1}$, Saša Dragović ${ }^{3}$, Nemanja Rančić1,2

Pseudoaneurizme lijenalne arterije predstavljaju ekstremno retko, ali potencijalno fatalno medicinsko stanje. U literaturi je do sada opisano ukupno manje od 250 slučajeva. Najčešći uzročnik ovog retkog stanja je pankreatitis. Bolesnici sa pseudoaneurizmama lijenalne arterije skoro uvek imaju ozbiljne kliničke simptome. Ruptura pseudoaneurizme može izazvati komplikacije sa fatalnim posledicama. Rad ima za cilj da prikaže mogućnosti radiološke dijagnostike pseudoaneurizme lijenalne arterije kod bolesnika sa hroničnim pankreatitisom. Bolesniku su inicijalno urađene ultrazvučna i kolor dopler dijagnostika, pomoću kojih je otkrivena promena suspektna na pseudoaneurizmu lijenalne arterije. Nakon ultrazvučnog pregleda sa kolor doplerom, urađene su CT angiografija i digitalna subtrakciona angiografija, kojima je potvrđena inicijalna dijagnoza. Bolesnik je lečen hirurški, a histopatološkim nalazom definitivno je postavljena dijagnoza pseudoaneurizme lijenalne arterije.

Acta Medica Medianae 2019;58(3):177-183.

Ključne reči: pseudoaneurizma lijenalne arterije, radiološka dijagnostika, ultrazvuk, CT, DSA 